\title{
Astringency Removal and Ripening in Persimmons Treated with Ethanol and Ethylene
}

\author{
Kiminori Kato \\ Fukushima Fruit Tree Experiment Station, Iizaka, Fukushima, 960-02, \\ Japan
}

Additional index words. postharvest, physiology, marketing, quality, Diospyros kaki

Abstract. Treating astringent persimmons (Diospyros kaki L.) with 3 to $5 \mathrm{nl} \mathrm{C}_{2} \mathrm{H}_{4} / \mathrm{ml}$ following the application of ethanol to reduce tannins decreased fruit firmness and increased color, producing high-quality fruits in a short period. The decrease in firmness was proportional to the period of exposure to ethylene. These effects of ethylene were less-marked in fruits with relatively poor color and at $30 \mathrm{C}$ rather than at $20 \mathrm{C}$.

The astringency of persimmon fruit is generally removed by treatment with either ethanol or $\mathrm{CO}_{2}$. Removal of astringency with ethanol is carried out by packing fruits in a carton (5 to $15 \mathrm{~kg}$ net weight), sealing them after spraying them with aqueous ethanol $(30 \%$ to $40 \%)$, and then storing them for 10 to 14 days at 10 to $15 \mathrm{C}$. This method produces firm, high-quality fruits with jelly-like texture, sweet taste, and good orange color, but is commercially impractical because of the long time required. Removal of astrin gency with $\mathrm{CO}_{2}$ is carried out by holding fruit for 1 to 3 , days in high- $\mathrm{CO}_{2}$ concentrations. This method is suitable commercially because large quantities of fruits can be rendered nonastringent in a short period. Its application is, however, confined to fruits picked near table-ripe, because $\mathrm{CO}_{2}$ retards fruit ripening.

Persimmon fruit of the late cultivar Aizumishirazu, which grows in the northern area of Japan, are usually picked rather immature to attract high prices for early shipments and/or to avoid frost damage. There has been no satisfactory commercial method for removing astringency from these fruit, because the fruit must also be ripened.

Rapid removal of astringency from 'Aizumishirazu' fruit was achieved by treating the fruit with ethanol at a high temperature, but the fruit remained unripe (Kate, 1987) Ethylene treatment following the ethanol treatment might ripen the treated fruit, as suggested by Eaks (1967), Iwata et al. (1970), Kato (1987), and Takada (1975). There is, however, little information on the practical requirements for treating persimmon fruit with ethylene. I, therefore, investigated the use of ethanol to remove astringency and ethylene to ripen unripe fruits of astringent persimmon cultivars.

Received for publication 16 Aug. 1988. I thank C. Ogaki at the Univ. of Thukuba and Michael S. Reid at the Univ. of California for their advice in manuscript preparation. The cost of publishing this paper was defrayed in part by the payment of page charges. Under postal regulations, this paper therefore must be hereby marked advertisement solely to indicate this fact.
Fruit of the astringent cultivars Hiratanenashi and Aizumishirazu, harvested from 20 Oct. to 6 Nov. during 1980-83, were used for the experiments. In all experiments, the fruit was placed in chambers held at 20, 25, or $30 \mathrm{C}$ and ventilated with a flowing air stream. After a few hours, ethanol was in-
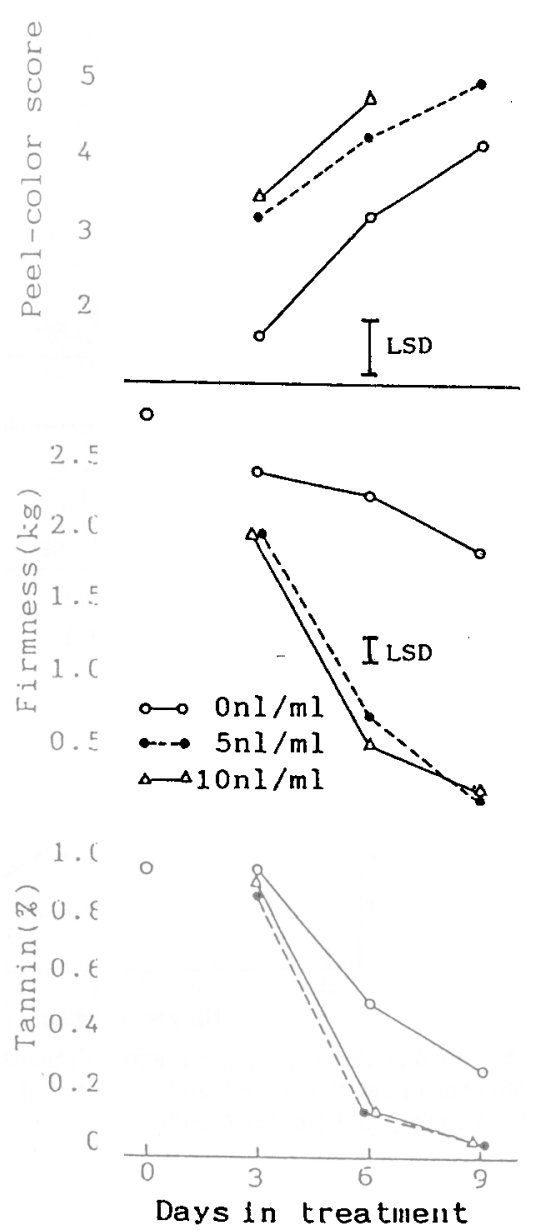

Fig. 1. Changes in tannin concentration, firmness $(\mathrm{kg} \times 9.8=\mathrm{N})$, and peel-color score of 'Hiratanenashi' fruit treated with ethanol and then with 0,5 , and $10 \mathrm{nl} \mathrm{C}_{2} \mathrm{H}_{4} / \mathrm{ml}$ during 3 days at $20 \mathrm{C}$, followed by storage at the same temperature. $\mathrm{LSD}_{(0.05)}$ is for day 6 only. troduced by passing the incoming air through bottles containing $10 \%$ (30C) to $20 \%$ (20C) aqueous ethanol for 1 day. Thereafter, fruit was treated with ethylene as metered into the air stream by a modification of the method of Pratt et al, (1960). The experiments tested the effects of ethylene concentration, period of exposure to ethylene, fruit maturity, and temperature during the ethylene treatment. After 3 days, when the exposure to ethylene was terminated, the fruit was removed from the chambers and transferred to rooms at 15 or 20C.

Fruit astringency was estimated by measuring soluble tannin concentration in the flesh, and ripeness was determined by measuring fruit firmness and/or, rating peel color. The peel color score ranged from 1 (very poor) to 5 (very good). The other measurements were made by the methods reported previously (Kate, 1984a, 1984b). Ripeness data were analyzed using the $t$ test.

Peel color development, as well as fruit firmness loss, was affected by ethylene treatment. Peel color scores were high in ethylene-treated 'Hiratanenashi' (Fig. 1), but the difference was less pronounced in 'Aizumishirazu' fruit (Fig. 2). Persimmon fruit normally become soft after becoming fully colored (Iwata et al., 1969). The ripening of ethylene-treated fruit is different from normal ripening in that softening precedes coloring.

'Hiratanenashi' fruit treated with 5 or 10 $\mathrm{nl} \mathrm{C}_{2} \mathrm{H}_{4} / \mathrm{ml}$ quickly became soft and mushy (Fig.1). In 'Aizumishirazu' fruit, the re-

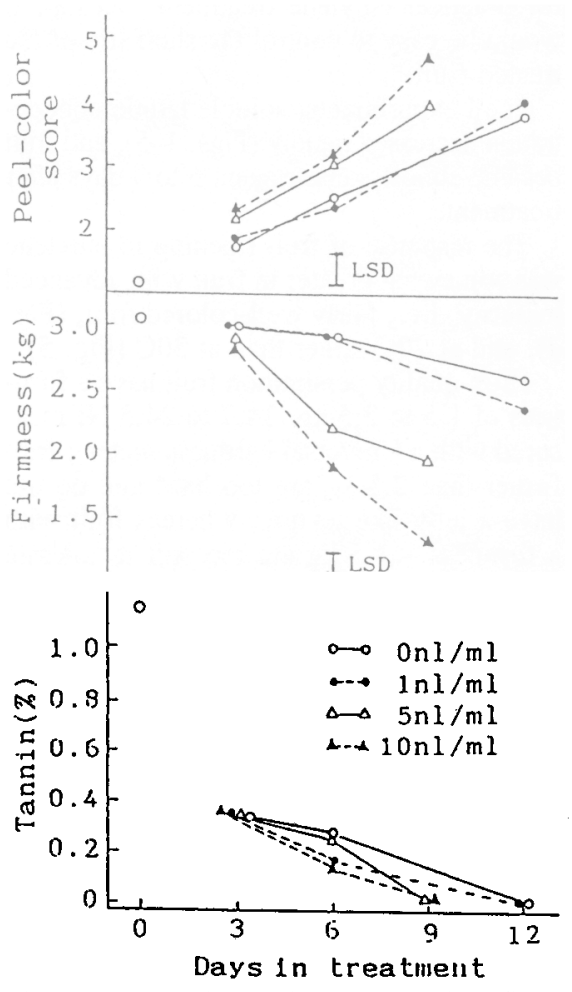

Fig. 2. Changes in tannin concentration, firmness, and peel-color score of 'Aizumishirazu' fruit treated with ethanol and then with $0,1,5$, and $10 \mathrm{nl} \mathrm{C}_{2} \mathrm{H}_{4} / \mathrm{ml}$ during 3 days at $30 \mathrm{C}$, followed by storage at $15 \mathrm{C}$. $\operatorname{LSD}_{(005)}$ is for day 6 only. 


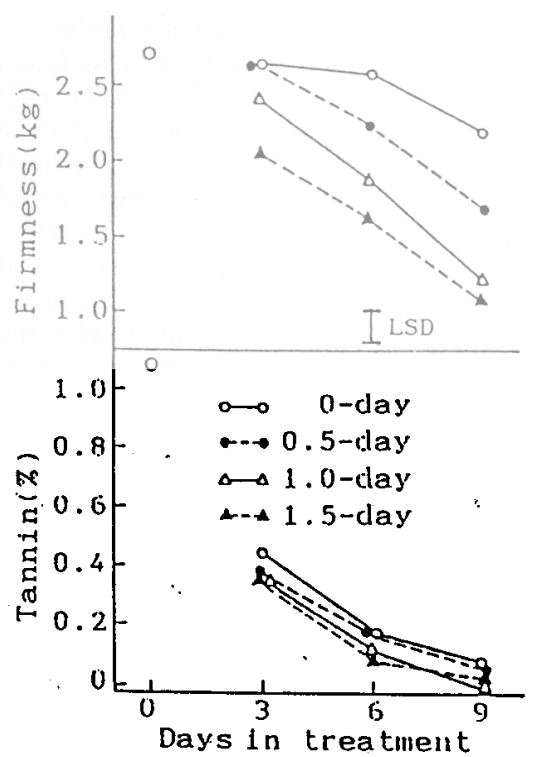

Fig. 3. Changes in tannin concentration and firmness of 'Aizumishirazu' fruit treated with

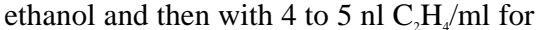
periods of $0,0.5,1.0$, and 1.5 days during 3 days at $25 \mathrm{C}$, followed by storage at $15 \mathrm{C}$. $\operatorname{LSD}_{(0.05)}$ is for day 6 only.

sponse to ethylene was proportional to the concentration used; fruit treated with $1 \mathrm{nl}$ $\mathrm{C}_{2} \mathrm{H}_{4} / \mathrm{ml}$ were a little softer 12 days after treatment than untreated fruit, whereas fruit treated with $10 \mathrm{nl} \mathrm{C}_{2} \mathrm{H}_{4} / \mathrm{ml}$ softened rapidly after treatment (Fig. 2). Softening was proportional to the period of exposure to ethylene (Fig. 3). This would provide a basis for practical ethylene treatment, because it would be easy to control the shelf life of the treated fruit.

In all experiments, soluble tannin concentration-decreased rapidly (Figs. 1-5), and fruit became almost nonastringent 6 to 9 days after treatment.

The response of fruit ripening to ethylene was somewhat greater in fruit with advanced maturity, i.e., fairly well-colored fruit, (Fig. 4), and at 20C rather than at 30C (Fig. 5).

High-quality persimmon fruit have a firmness of 1.5 to $2.5 \mathrm{~kg}$ (14.7 to $24.5 \mathrm{~N}$; measured with a Universal hardness meter); fruit firmer than $2,5 \mathrm{~kg}$ are too hard and do not have a jelly-like texture, whereas fruit with a firmness $<1.5 \mathrm{~kg}$ are too soft to tolerate the physical handling associated with marketing. Since $\approx 7$ days are required in marketing, from sorting through sale, it is desirable to have fruit with a firmness $<2.5$ $\mathrm{kg}$ after astringency removal and ripening, but that do not soften below $1.5 \mathrm{~kg}$ for several days. Therefore, 'Aizumishirazu' fruit should be treated with ethanol to remove astringency then ripened with 3 to $5 \mathrm{nl} \mathrm{C}_{2} \mathrm{H}_{4} /$ $\mathrm{ml}$ for 0.5 to I. O-day, depending on fruit maturity and treatment temperature.

\section{Literature Cited}

Eaks, I.L. 1967. Ripening and astringency removal in persimmon fruits. Proc. Amer. Soc. Hort. Sci. 91:868-875.

Iwata, T., K. Nakagawa, and K. Ogata. 1969. Relationship between the ripening of harvested
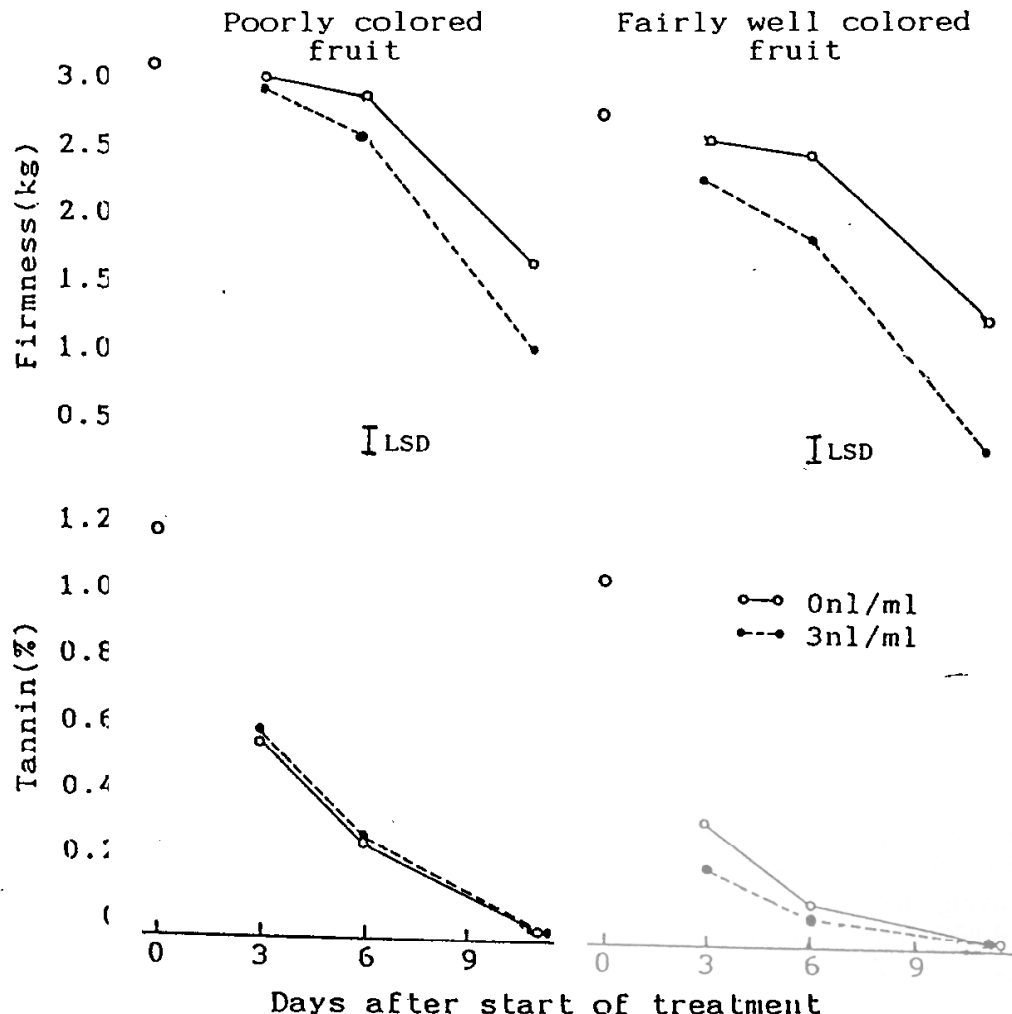

Fig.4. Changes in tannin concentration and firmness of poorly and fairly well-colored 'Aizumishirazu' fruit treated with ethanol and then treated with 0 and $3 \mathrm{nl} \mathrm{C}_{2} \mathrm{H}_{4} / \mathrm{ml}$ during 3 days at $25 \mathrm{C}$, followed by storage at $15 \mathrm{C}$. $\operatorname{LSD}_{(0.05)}$ is for day 6 only.

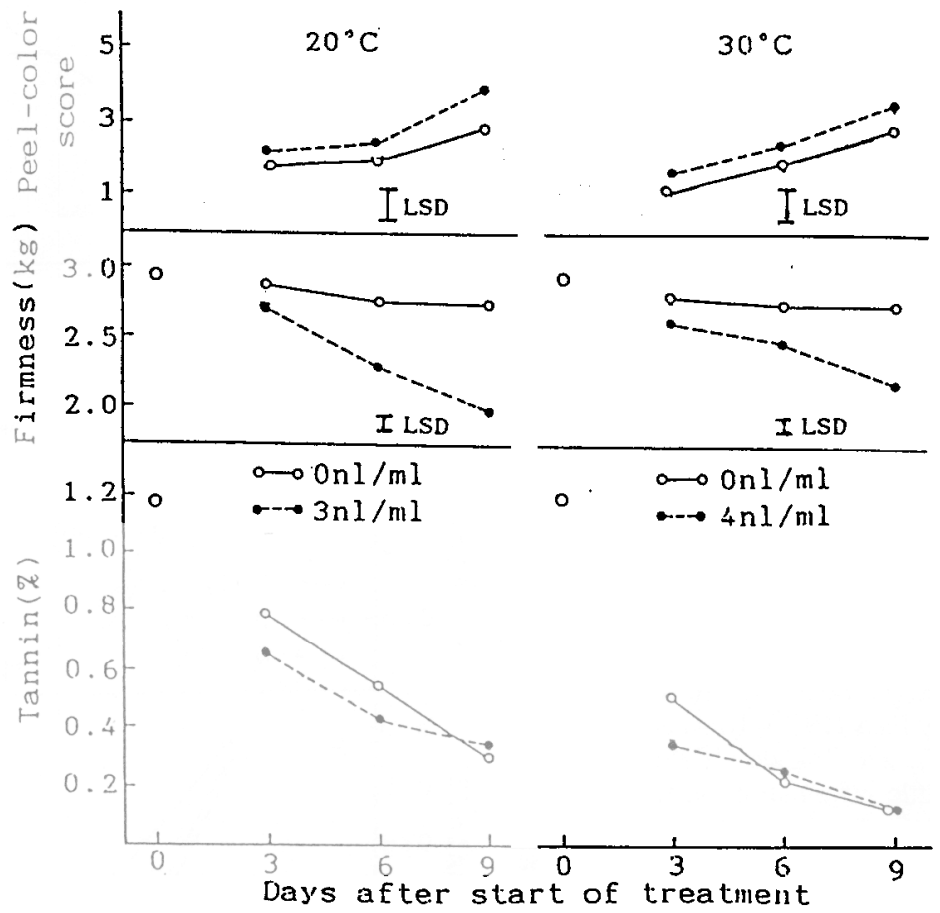

Fig.5. Changes in tannin concentration, firmness, and peel-color score of Aizumishirazu' fruit treated with ethanol and then with 0 and 3 or $4 \mathrm{nl} \mathrm{C}_{2} \mathrm{H}_{4} / \mathrm{ml}$ during 3 days at 20 or $30 \mathrm{C}$, followed by storage at $15 \mathrm{C} . \mathrm{LSD}_{(0.05)}$ is for day 6 only.

fruits and the respiratory pattern: I. On the class of respiratory pattern of Japanese persimmons. J. Jpn. Soc. Hort. Sci. 38:194-201.

Iwata, T., I. Omata, and K. Ogata. 1970. Relationship between the ripening of harvested fruits and the respiratory pattern: 111 . Changes of ethylene concentration in fruits and responses to applied ethylene with relation to the respiratory pattern. J. Jpn. Soc. Hort. Sci. 38:350-358.

Kate, K. 1984a. The condition of tannin and sugar extraction, the relation of tannin concentration to astringency and the behavior of ethanol during the de-astringency by ethanol in persimmon fruits. J. Jpn. Soc. Hort. Sci. 53:127-134. 
Kate, K. 1984b. Astringency removal and ripening as related to ethanol concentration during the de-astringency by ethanol in persimmon fruits. J. Jpn. Soc. Hort. Sci. 53:278-289.

Kate, K. 1987. Large-scale trials for the short- term de-astringency in persimmon fruits by ethanol. J. Jpn. Soc. Hort. Sci. 56:92-100.

Pratt, H. K., M. Workman, F.W. Martin, and J.M Lyons. 1960. Simple method for continuous treatment of plant material with metered traces of ethylene or other gases. Plant Physiol. 35:609611

Takada, M. 1975. Effects of ethylene on the respiration and ripening of fruits. J. Jpn. Soc. Hort. Sci. 44:82-88.

HoRTSCIENCE 25(2):207-209. 1990.

\title{
Ethylene Production in Netted Muskmelon Subjected to Postharvest Heating and Refrigerated Storage
}

\author{
James R. Dunlap \\ Texas Agricultural Experiment Station, 2415 E. Highway 83, Weslaco, \\ TX 78596
}

\author{
Sarah E. Lingle \\ U.S. Department of Agriculture, Agricultural Research Service, Weslaco, \\ TX 78596
}

\section{Gene E. Lester \\ U.S. Department of Agriculture, Agricultural Research Service, Weslaco, TX 78596}

\begin{abstract}
Additional index words. Cucumis melo, ethylene-forming enzyme, wound-induced
\end{abstract} ethylene, temperature stress, 1-aminocyclopropane-1-carboxylic acid

\begin{abstract}
Postharvest ethylene production and ACC levels were determined in netted muskmelon fruits (Cucumis melo L. var. reticulatus 'Magnum 45') exposed to temperature extremes by heating for $3 \mathrm{hr}$ at $45 \mathrm{C}$ and/or storage at $4 \mathrm{C}$. The possibility of using seal-packaging to protect the fruit against temperature-induced changes in ethylene production was examined by wrapping melons before treatment with a high-density polyethylene (HDPE) shrink-film. Ethylene production measured in fruit immediately after heating or removal from refrigeration was only $30 \%$ of the level determined before treatment, and continued to decline during refrigerated storage. However, the concentration of $\mathrm{ACC}$ in these same tissues remained constant or even increased slightly during storage. Wrapping fruit in HDPE film had no effect on the tissue concentrations of ACC or capacity for ethylene synthesis. In contrast to initial measurements, heated or refrigerated fruit held at room temperature $(25 \mathrm{C})$ for $24 \mathrm{hr}$ produced ethylene at rates that equalled or exceeded the levels for freshly harvested fruit. These results strongly suggest that temperature-imposed restrictions on ethylene synthesis by netted muskmelon fruit are reversible and occur at the step responsible for converting ACC to ethylene via EFE rather than in the synthesis of ACC. Chemical names used: 1aminocyclopropane-1-carboxylic acid (ACC).
\end{abstract}

During commercial harvest and storage operations, netted muskmelon fruit can be subjected to a 50C difference in temperature within $12 \mathrm{hr}$. For example, the internal temperature of muskmelon fruit can reach 42 to 47C when exposed to direct sunlight (Kasmire et al., 1961; Lipton et al., 1987). Solar heating of netted muskmelon fruit can accelerate softening and cause a loss of quality (Kasmire, et al., 1961). Immediately after harvest, netted muskmelon are routinely hy-

Received for publication 22 Feb. 1988. Mention of a proprietary product does not constitute endorsement or recommendation for its use by the USDA. The cost of publishing this paper was defrayed in part by the payment of page charges. Under postal regulations, this paper therefore must be hereby marked advertisement solely to indicate this fact. drocooled to near $10 \mathrm{C}$ and placed into storage at 4C (Hardenburg et al., 1986). Water heated to $57 \mathrm{C}$ has been used in conjunction with fungicides to control postharvest diseases in netted muskmelons (Carter, 1981). Postharvest exposure to high or low temperatures above freezing has been identified as the cause of injury and product losses in diverse fruits and vegetables (Ryan and Lipton, 1979; Weichmann, 1987).

Ripening in climacteric fruit, including netted muskmelon, is characterized by an increase in ethylene production coincident with an accelerated rate of senescence (McGlasson, 1985). This change is clearly demonstrated in netted muskmelon, where the postharvest life, even at $4 \mathrm{C}$, is $<14$ days (Ryan and Lipton, 1979). Physical injury or wounding is capable of stimulating the synthesis of both ethylene and ACC, the im- mediate precursor to ethylene, in preclimacteric as well as fully ripe muskmelon fruit (Dunlap and Andersen, 1985; Yang and Hoffman, 1984). Injury caused by exposure of fruit to extreme temperatures during postharvest handling may be reflected as a change in the ethylene biosynthetic mechanism. For example, ACC is reported to accumulate during refrigerated storage of 'Honey Dew' muskmelon (Lipton et al., 1987). Under certain conditions, increases in ethylene production can accelerate ripening and shorten the postharvest life of horticultural crops (Kader, 1985).

Although the mechanism of temperature injury remains unclear, the response in tomato and papaya has been attributed to a loss of membrane function and increased cellular leakage (Chan, 1986; Saltveit and Cabrera, 1987). Heating to $45 \mathrm{C}$ or storage of netted muskmelon fruit at 4C elevates solute leakage, indicating injury to the tissue (Lester et al., 1988). Protection from temperature injury has been achieved in other fruits and vegetables by individual seal-packaging in high-density polyethylene (HDPE) films (BenYehosua, 1985). The individual seal-pack' aging effectively delays senescence and extends the shelf-life of citrus and bell pepper, presumably by decreasing the loss of tissue moisture. The storage life of refrigerated netted muskmelon fruit is extended by 30 days with HDPE shrink-film wrap (Lester and Bruton, 1986). Consequently, studies were conducted to determine the effect of temperature extremes present during commercial handling on the ethylene biosynthetic mechanism in netted muskmelon fruit and the protection against injury provided with film wrap packaging.

Full-slip, 'Magnum 45' netted muskmelon were harvested just after sunrise from a commercial field near Weslaco, Texas. All of the melons were dipped in Imazalil and one-half of the sample population wrapped in HDPE shrink-film wrap described by Lester et al. (1988). Each treatment was conducted with at least three melons. Wrapped and nonwrapped fruit were heated at 45C and $100 \%$ $\mathrm{RH}$ for $3 \mathrm{hr}$ by incubation in a controlledenvironment chamber. Internal fruit temperatures were monitored in the direction of the seed cavity with a thermocouple installed in a 76-mm hypodermic needle. After heat treatment, the fruit were packed in commercial fiberbox containers and refrigerated at 4 $\pm 1 \mathrm{C}$ and $90 \pm 5 \% \mathrm{RH}$ for $0,6,12$, or 18 days. A subsample of untreated fruit was held at room temperature $(25 \mathrm{C})$

Using cork borers, tissue cylinders $8 \mathrm{~mm}$ in diameter were taken along the equatorial plane of each fruit and cut to uniform length of $30 \mathrm{~mm}$. One tissue cylinder was placed 